\title{
The role of Rabconnectin3a in cilia length regulation
}

\author{
B Tavares, ${ }^{*}$ P Pintado, SS Lopes \\ From Cilia 2014 - Second International Conference \\ Paris, France. 18-21 November 2014
}

\section{Background}

Using the zebrafish mutant for the deltaD gene $\left(\right.$ dld $\left.^{-/}\right)$, it was shown the involvement of Notch signaling in the control of cilia length in the cells of the fish laterality organ (Kupffer's Vesicle, KV) [1]. Further research based on KV specific microarray screening allowed the discovery of several genes with differential expression. Of these, $23 \%$ were associated with ciliogenesis and upon analysis, many proved to be involved in cellular trafficking.

Rabconnectin $3 a$ or $r b c n 3 a$ was strongly downregulated in $d l d^{-1} \mathrm{KV}$ cells. Homologs of this gene have been associated with Notch signaling in Drosophila and mammalian cells through the regulation of the V-ATPase activity $[2,3]$. $R b c n 3 a$ had also been associated with vesicular acidification in zebrafish hair cells [4] and with vesicular endocytosis and maturation in zebrafish neural crest migration [5].

\section{Objective}

We investigated the role of Rbcn3a in cilia length regulation.

\section{Methods}

We used a Morpholino against $r b c n 3 a$ and fluorescent confocal imaging to explore cilia length. Furthermore we observed the consequences of reduced Rbcn3a in organ situs by ISH. We also performed rescue experiments by injecting $r b c n 3 a$ full length mRNA at 1-cell stage $d l d^{-/-} \mathrm{KO}$ mutants.

\section{Results}

We showed that the downregulation of $r b c n 3 a$ negatively regulates cilia length and that this can be rescued by $r b c n 3 a$ overexpression in $d l d^{-/}$embryos.

CEDOC, Chronic Diseases Research Center, NOVA Medical School / Faculdade de Ciências Médicas, Universidade Nova de Lisboa, Campo Dos Mártires Da Pátria, 130, 1169-056 Lisbon, Portugal

\section{Conclusion:}

The ciliary phenotype in $d l d^{-/-}$mutants is partially due to the downregulation of $r b c n 3 a$. Our hypothesis is that a generalized decrease in endocytic acidification, by deregulating the V-ATPase activity, results in shorter cilia.

Published: 13 July 2015

\section{References}

1. Lopes SS, Lourenco R, Pacheco L, Moreno N, Kreiling J, Saude L: Notch signalling regulates left-right asymmetry through ciliary length control. Development 2010, 137(21):3625-3632.

2. Yan $Y$, Denef $N$, Schupbach $T$ : The vacuolar proton pump, V-ATPase, is required for notch signaling and endosomal trafficking in Drosophila. Dev Cell 2009, 17(3):387-402.

3. Sethi N, Yan Y, Quek D, Schupbach T, Kang Y: Rabconnectin-3 is a functional regulator of mammalian Notch signaling. J Biol Chem 2010, 285(45):34757-34764

4. Einhorn Z, Trapani JG, Liu Q, Nicolson T: Rabconnectin 3a promotes stable activity of the $\mathrm{H}+$ pump on synaptic vesicles in hair cells. J Neurosci 2012, 32(32):11144-11156.

5. Tuttle A, Hoffman TL, Schilling TF: Rabconnectin-3a regulates vesicle endocytosis and canonical Wnt signaling in zebrafish neural crest migration. PLOS Biol 2014, 12(5):e1001852.

doi:10.1186/2046-2530-4-S1-P70

Cite this article as: Tavares et al:: The role of Rabconnectin3a in cilia length regulation. Cilia 2015 4(Suppl 1):P70.

Submit your next manuscript to BioMed Central and take full advantage of:

- Convenient online submission

- Thorough peer review

- No space constraints or color figure charges

- Immediate publication on acceptance

- Inclusion in PubMed, CAS, Scopus and Google Scholar

- Research which is freely available for redistribution
C Biomed Central

C 2015 Tavares et al. This is an Open Access article distributed under the terms of the Creative Commons Attribution License (http:// creativecommons.org/licenses/by/4.0), which permits unrestricted use, distribution, and reproduction in any medium, provided the original work is properly cited. The Creative Commons Public Domain Dedication waiver (http://creativecommons.org/publicdomain/ zero/1.0/) applies to the data made available in this article, unless otherwise stated. 